\title{
Mewaspadai Secondary Traumatic Stress Saat Memberi Pelayanan Konseling
}

Amirah Diniaty

Universitas Negeri Padang

\begin{abstract}
Not infrequently counselor faced with complicated problems and traumatic outstanding experienced by the client. According to Figley and Stamm (in Stamm, 1999), a trauma counselor can come to experience some of the symptoms are similar to Post Traumatic Stress Disorder (PTSD), which is owned by their clients. Figley (in Richardson, 2001) defines this situation with Secondary Traumatic Stress (hereinafter referred to as STS), which is something that occurs naturally, is a behavioral and emotional consequences as a result of knowledge about a traumatic event experienced by a significant other. The term 'secondary' refers to the fact that the trauma experienced by others, but then experienced by the participating parties observe, giving aid, or listen to the story (Sidabutar, 2003). This is the "price" of giving attention, care, and help individuals who experience trauma. Counselors need to be aware of this condition. Discussion professional is one important activity that needs to be done.
\end{abstract}

Keyword: Konselor, Secondary Traumatic Stress, Konseling, Klien

Copyright (C 2014 IICE - Multikarya Kons (Padang - Indonesia) dan IKI - Ikatan Konselor Indonesia - All Rights Reserved

Indonesian Institute for Counseling and Education (IICE) Multikarya Kons

\section{PENDAHULUAN}

Sukses dalam proses konseling tergantung pada kerjasama Antara konselor dan klien (Kottler, Sexton \&Whiston, 1994; Okun and Kantrowits, 2008 in Samuel Gladding, 2012). Namun demikian Samuel T Gladding (2012: 38) menyatakan kepribadian konselor adalah hal yang sangat penting juga dalam konseling. Seorang konselor haruslah dewasa, ramah dan bisa berempati. Mereka harus altruistic (peduli pada kepentingan orang lain) tidak mudah marah atau frustrasi. Auvenshine dan Noffsinger (1984) dalam Samuel T. Gladding ( $2012: 44$ ) menjelaskan konselor yang efektif adalah konselor yang secara emosi dewasa, stabil, dan objektif. Mereka memiliki kesadaran diri, mantap dalam kesadaran tersebut serta mampu mengelola kelebihan dan kekurangan mereka secara realistis.

Begitu sempurna tuntutan bagi pribadi konselor menjadikan profesi ini tergolong dalam level penolong professional. Samuel T. Gladding (2012:45) menegaskan penolong professional adalah orang-orang yang telah dididik untuk membantu kegiatan pertolongan dalam tingkat preventif dan remedial. Penolong dalam tingkatan ini telah menjalani jenjeng pendidikan tingkat tinggi dan sudah dipersiapkan untuk menghadapi situasi-situasi yang tidak umum.

Salah satu situasi yang tidak umum dihadapi oleh konselor adalah peristiwa traumatis yang dihadapi klien. Traumatis artinya adalah keadaan jiwa atau tingkah laku yg tidak normal sbg akibat dari tekanan jiwa atau cedera jasmani; luka berat (http://kbbi.web.id/trauma, diakses tanggal 24 Februari 2014). 
Keberadaan klien yang trauma dan dilayani oleh konselor dalam proses konseling face-to-face, berarti hanya semata konselor pribadi yang mengetahui persoalan yang dialami oleh klien. Konselor yang adalah juga manusia dengan segenap kelebihan dan kekurangannya, serta hakikatnya sebagai makluk social membutuhkan orang lain. Profesionalisme dan naturalisme sebagai konselor dituntut untuk dapat membantu klien mengatasi traumanya tapi di sisi lain juga harus mampu memisahkan dirinya pribadi sebagai pemberi layanan. Ketika terjadi STS, apa yang harus dilakukan konselor? Selaku makluk social dan tenaga professional, tentunya konselor tidak bias membicarakan kondisi klien dan dirinya pada sembarangan orang. Dalam hal ini diskusi professional dan forum musyawarah guru pembimbing (MGP) dapat dijadikan sebagai wadah. Namun bagaimana batasan-batasan dalam membicarakan kondisi STS itu di diskusi professional tersebut perlu dipahami oleh konselor.

Tulisan ini berisi berupaya mengungkap kajian teoritis dan analisis yang terjadi dilapangan. Bagaimana sesungguhnya STS itu terjadinya, akibat dan upaya penangulangannya pada konselor. Inilah yang menjadi tujuan penulisan makalah ini. Sehingga diharapkan tulisan ini dapat bermanfaat bagi konselor yang mengalami STS atau yang belum mengalami dapat mengatasinya dan mencegahnya dengan tepat.

\section{HAKIKAT SECONDARY TRAUMATIC STRESS}

Peristiwa yang terjadi dalam kehidupan klien bisa saja menimbulkan bekas mendalam. Bekas yang dimaksud bukan saja secara fisik tetapi lebih kepada psikologis. Anda mungkin pernah mengalami kejadian secara fisik seperti jatuh dari ketinggian semisal memanjat batang pohon, lalu mengakibatkan tubuh anda cacat atau kaki anda patah. Kejadian jatuh dari pohon bukan hanya menimbulkan bekas pada fisik Anda yaitu kaki anda patah, tetapi juga dapat menyebabkan ketakutan pada diri Anda akan ketinggian. Saat menaiki tangga atau berada di gedung tinggi lalu anda melihat kebawah jantung anda berdegup kencang, kepala Anda tiba-tiba pusing, dan Anda bisa histeris. Anda mengalami peristiwa traumatis.

Lebih menarik lagi dalam tulisan ini saya cuplikan sebuah kisah tentang pengalaman traumatis luar biasa yang dialami seorang ibu. Kisah ini saya ambil dari cerita seseorang dalam media facebook, sebagai berikut :

Cerita itu tentang (A), seorang ibu rumah tangga asli Boyolali tapi tinggal di satu kota, lulusan Institut tertentu, yang pada 2006 lalu menggegerkan masyarakat karena membunuh ketiga anaknya yang masih kecil dengan cara membekap mereka dengan bantal sampai meninggal. Mungkin masih banyak yang ingat kasusnya. Banyak yang mengira bahwa alasan pembunuhan itu adalah karena Bu A depresi memikirkan masalah ekonomi dan mengkhawatirkan masa depan anaknya yang suram. Bu A kemudian diputus bebas oleh pengadilan dan diperintahkan untuk menjalani perawatan di Rumah Sakit Jiwa. Pak F kebetulan tergabung didalam tim psikologi yang memeriksa kondisi kejiwaan Bu A waktu itu, dan cerita latar belakang kenapa Bu A memutuskan untuk mengakhiri hidup anak2nya inilah yang mengundang kucuran airmata dan menegakkan bulu roma kaтi sетиа yang mendengarnya

Bu A sendiri, boleh dibilang adalah potret sempurna dari keberadaan seorang anak. Dari kecil sampai lulus, prestasi akademiknya selalu cemerlang. Pengalaman sosialnya juga bagus. Intinya, dari luar dia merupakan anak yang diidam-idamkan semиa orangtua, titik. Ketika kemudian menikah dan menjadi seorang ibu, dia juga tidak beda dengan ibu-ibu lainnya yang sangat menyayangi anak-anaknya, segenap jiwa dan raga. Lantas kenapa dia sampai memutuskan mengakhiri hidup anak-anaknya sendiri?? Sebelum mengungkapkan alasan yang berhasil digali oleh tim psikologi yang memeriksanya, Pak F menggambarkan suasana siang itu, ketika Bu A melaksanakan niat yang sudah bulat diambilnya sejak beberapa waktu sebelumnya. 
Siang itu si anak sulung N (6 tahun) baru pulang sekolah. Mungkin sekitar dhuhur, ketika sehabis sholat Bu A menyambut kedatangan si sulung dengan senyum dan pelukan sayang seperti biasa. Kemudian disiapkannya makan siang untuk $N$, ditemaninya si sulung makan siang bersama adiknya Fs (3 tahun, si anak tengah). Si bungsu U (9 bulan) saat itu sedang tidur siang.

Sepanjang makan siang itu, Bu A lebih banyak mengelus rambut anak2 dan menciumi kepala mereka daripada hari-hari yang lain. Setelah selesai disuruhnya $N$ dan Fs mandi. Sehabis mandi, mereka diberi pakaian yang nyaman dan dibedak seluruh tubuhnya sampai harum. Bu A kemudian menyuruh si sulung bermain di ruangan lain sementara dia mengantar si tengah tidur siang di kamar. (Aku tidak yakin yang mana diantara mereka yang lebih dulu diminta untuk tidur siang, tetapi kurang lebih begitu kejadiannya, satu anak diantar tidur siang dan yang lain bermain di luar kamar).

Bu A tak lupa mengajak si anak membaca doa sebelum tidur, bahkan dengan lembut menyanyikan beberapa lagu pengantar tidur yang diminta anaknya. Ketika kemudian dia yakin bahwa si anak sudah tertidur pulas, diambilnya bantal dan ditangkupkannya ke wajah anaknya tersebut....kuatkuat....lama....cukup lama sampai nafas si anak berhenti...

Kemudian Bu A memanggil si anak lain yang sedang bermain di luar kamar. "Ayo, temani saudaramu tidur siang nak...” Dengan kelembutan dan kasih sayang yang sama diantarkannya si kecil ke hangatnya tidur siang dan mimpi yang indah... Dan Bu A sekali lagi mengambil bantal untuk ditangkupkan ke wajah si kecil... Si kecil pun kembali meregang nyawa tepat disamping saudara yang tanpa sepengetahuannya sudah lebih dulu meninggalkannya.

Dan terakhir, si bungsu $U$, yang masih bayi dan terlelap tidur pun, kemudian menyusul kedua kakaknya...meregang nyawa didalam pelukan Bu A...

$* * *$

Kisah diatas sangat mengerikan buat kita semua, tentu saja... Tetapi kalau ada yang lebih mengerikan adalah alasan Bu A melakukannya. Kalau melihat latar belakang pendidikannya, tentu hal seperti ini kurang masuk akal. Seharusnya Bu A sebagai seseorang yang berpendidikan tinggi, lebih bisa mengatasi tekanan mental maupun emosi didalam dirinya. Tetapi apa yang dialaminya (seperti yang diceritakan oleh Pak F di PSC) ternyata memang sangat besar, jauh lebih besar daripada yang kami semua kira. Setelah melewati penggalian yang lama dan dalam oleh tim psikologi, terungkap alasan sebenarnya dibalik keputusan Bu Ani...

A dari luar memang potret anak yang sempurna. Tetapi sangat ironis dan dramatis, kecemerlangan dirinya dihadapan semua orang, ternyata tidak bisa dilihat oleh si Ani terpancar keluar dari mata ibu kandungnya sendiri. Ibunda dari A, diceritakan tidak pernah merasa puas dengan apapun yang dicapai oleh putrinya. Dan sang Ibu adalah tipe wanita yang SANGAT PENGOMEL!! Sekeras apapun Ani berusaha memberikan yang terbaik dalam hidupnya, tetap saja yang dia dapat ketika pulang adalah omelan tidak puas dari ibunya. Sebanyak apapun nilai A yang dia dapat, begitu berhadapan dengan ibunya langsung menjadi tidak berarti karena akan selalu dibandingkan dengan prestasi teman lain yang nilai A nya lebih banyak. Setinggi apapun prestasi yang dicapai A, yang dilihat sang Ibu adalah orang lain yang berprestasi lebih tinggi lagi. Omelan demi omelan tanda ketidakpuasan, sepertinya hanya itu yang Ani dapat selama dia tumbuh dewasa. Dan itu merupakan sebuah luka yang besar yang kemudian berurat akar dalam dirinya. 
Ketika Ani menikah serta melahirkan ketiga anak-anaknya, omelan-omalen tak puas dari sang ibu bahkan sama sekali bukanlah yang terburuk yang bisa terjadi...

Selama mendidik putra-putrinya, pelan-pelan Ani belajar dan menyadari bahwa kebiasaan ibunya mendidik dia dulu, tanpa sadar seringkali dilakukannya pada anak-anaknya. Sekeras apapun niatnya untuk bertekad tidak mau meniru cara mendidik ibunya yang penuh omelan tak puas itu, tetapi sesering itu juga tanpa disadarinya, itu terjadi... Anaknya tumbuh dengan omelan yang (walaupun tidak sebanyak dirinya, tetapi) mirip dengan yang selalu diterimanya dulu dari sang ibu...

A kemudian belajar dan menemukan bahwa luka yang ditorehkan sang ibu didalam hidupnya, tak mungkin terhapuskan... Lebih buruk lagi, kemudian dia memutuskan bahwa luka itu menular, menurun dan melukai anak-anaknya juga... Luka yang kali ini dia timbulkan sendiri.... Dia torehkan tanpa sadar kedalam hidup anak-anak yang dicintainya... Luka yang menyebar dengan kuat, bahkan tekad bulatnya yang kuat untuk menjadi ibu yang baik pun, tak kuasa menghentikannya...

Sebagai seorang ibu, A merasa bahwa dia adalah ibu yang sudah terlanjur terlaknat. Terlaknat oleh luka dan kebiasaan buruk tak tersembuhkan yang sudah kadung ditorehkan ibunya dulu. Dan lebih buruk lagi, sekarang, tanpa dia sadari dan bisa hentikan, dia akan mencetak 3 calon orangtua yang terlaknat juga, yaitu anak-anaknya. Ani merasa nanti ketika anak2nya sudah menjadi orangtua, tanpa sadar mereka pasti akan mewarisi caranya memperlakukan anak-anak, sekeras apapun mereka mungkin akan mencoba menghentikannya.

Tak terbayangkan oleh A nasib cucu dan keturunannya, kalau luka ini akan terus menjalar turun kepada keturunannya. Kalau omelan-omelan jahanam itu akan terus menelan korban, melukai hidup banyak orang karena tidak bisa dihentikan penularannya. Melukai banyak orang yang kemudian hanya akan berakhir sama, menjadi penyebar dan pembawa kebiasaan terkutuk itu...

Konon, Bu A masih mengakui betapa cintanya dia pada sang bunda... Tetapi pada akhirnya, sebagai seorang ibu yang juga sangat mencintai $N$, Fs dan U, Bu A memutuskan bahwa dia tidak sanggup lagi mencintai anak-anaknya... Tidak dengan cara seperti itu...

$* * *$

Cerita di atas, kalau ditindaklanjuti dengan konseling misalnya Bu A adalah klien Anda..maka akan mungkin Anda akan memikirkan $\mathrm{Bu} \mathrm{A}$ diluar proses konseling, membayangkannya andai saja bu A ketemu dengan Anda sebelum dia membunuh ke-3 anaknya. Mungkin saja itu akan menyebabkan Anda menjadi mengalami ketakutan/trauma menghadapi anak kandung Anda sendiri, terbayang-bayang kejadian yang dialami oleh bu A. Maka bahasan ini menyangkut tentang kejadian traumatis yang mungkin dialami konselor dalam membantu klien yang mengalami trauma.

Bidang traumatologi (studi mengenai individu yang mengalami trauma) telah mencapai perkembangan yang pesat di akhir dekade ini (Figley, 1995). Salah satu kontribusinya adalah meningkatnya kesadaran bahwa seseorang akan mengalami dampak psikologis yang berat ketika mengalami kejadian yang traumatik. Oleh sebab itu, pada tahun 1980, American Psychiatric Association mempublikasikan adanya diagnosis Post Traumatic Stress Disorder(PTSD) dalam Diagnostic and Statistic Manual of Mental Disorder (Third Edition) (DSM-III). Diagnosis ini melihat simtom-simtom yang umumnya dialami oleh individu-individu yang mengalami trauma 
sebagai gangguan psikiatris. PTSD merepresentasikan betapa berbahayanya pengaruh biopsikososial dari pengalaman traumatis.

Konsep PTSD mendorong penelitian-penelitian di bidang traumatologi. Dari ratusan penelitian dilaporkan bahwa ternyata individu yang tergolong mengalami trauma bukan hanya korban trauma itu sendiri (victims) tapi juga mencakup mereka yang terkena trauma secara tidak langsung (Pickett, 1998). Atau dengan kata lain, individu dapat mengalami trauma tanpa harus secara fisik berhadapan dengan peristiwa traumatik atau mendapatkan ancaman bahaya secara langsung. Selain itu, hanya dengan mendengar tentang kejadian traumatik itupun dapat berpotensi untuk membawa kondisi traumatik. Tidak hanya keluarga dari seseorang yang mengalami trauma yang rentan terhadap trauma sekunder, tetapi juga para pekerja kesehatan mental dan orang-orang lain yang ingin menolong korban (Figley, 1995).

Hal ini dijelaskan oleh Charles R.Figley dan B.Hudnall Stamm (Stamm, 1999), yang bekerja menangani klien yang trauma pada sebuah Trauma Center. Ia menyadari adanya suatu efek negatif yang dialami oleh para konselor. Efek ini justru muncul karena upaya seorang konselor dalam memberikan perhatian dan berempati kepada klien serta dorongan yang kuat untuk membantu klien. Menurut Figley dan Stamm (dalam Stamm, 1999), seorang konselor trauma bisa ikut mengalami beberapa simtom yang serupa dengan Post Traumatic Stress Disorder (PTSD) yang dimiliki oleh klien mereka. Figley (dalam Richardson, 2001) mendefinisikan situasi ini dengan Secondary Traumatic Stress (selanjutnya disebut STS), yaitu suatu hal yang terjadi secara natural, merupakan suatu konsekuensi tingkah laku dan emosi sebagai akibat dari pengetahuan mengenai suatu peristiwa trauma yang dialami oleh significant other. Istilah 'sekunder' mengacu pada kenyataan bahwa trauma itu dialami oleh orang lain, tetapi kemudian ikut dialami oleh pihak yang mengamati, memberikan bantuan, atau mendengarkan kisahnya (Sidabutar, 2003). Figley (1995) juga menyebut kondisi tersebut sebagai "reaksi secondary catastrophic stress", yang berarti bahwa empati terhadap pengalaman orang lain menghasilkan ketegangan emosional (seperti kesedihan, kemarahan, dll). Hal ini merupakan "harga" dari memberikan perhatian, kepedulian, dan pertolongan pada individu yang mengalami trauma.

Ppenjelasan di atas sebagai argumentasi peristiwa STS dapat terjadi pada konselor. Konselor sebagai tenaga professional yang membantu klien agar terlepas dari masalah trauma yang dialaminya, juga dapat dijangkiti oleh STS.

Fenomena tentang STS juga diasosiasikan dengan "cost of caring" terhadap penderitaan emosional orang lain (Figley dalam Rudolph, Stamm, danStamm, 1997). Adanya suatu perasaan simpati yang mendalam dan kesedihan terhadap orang lain yang menderita, disertai dengan keinginan yang kuat untuk meringankan penderitaan mereka dan menghilangkan faktor penyebabnya menyebabkan seseorang mudah untuk mengalami STS (Joinson, dalam Stamm, 1999).

Berdasarkan definisi di atas, maka STS merupakan istilah yang digunakan untuk mendeskripsikan gangguan atau rasa sakit psikologis yang berkembang pada para profesional kesehatan mental yang bekerja dengan klien yang mengalami trauma (Chrestman dalam Stamm, 1999). Meskipun STS merupakan suatu konsekuensi yang alamiah akibat seseorang mendampingi orang lain yang mengalami trauma, namun tentu saja konsekuensi ini dapat menimbulkan stres yang sangat berat.

\section{DAMPAK SECONDARY TRAUMATIC STRESS BAGI KONSELOR}

Para peneliti telah membandingkan efek trauma klien pada pekerja kesehatan mental dengan simtomsimtom PTSD (Conrad dan Perry dalam Hesse, 2002). Mereka sependapat bahwa bekerja dengan klien yang mengalami trauma memiliki efek yang tak dapat dielakkan, mengganggu, dan jangka panjang pada terapis, dan bahwa reaksi ini mungkin saja terjadi tanpa memandang suku, jenis kelamin, usia, dan tingkat keahlian atau profesional seseorang (Edelwichdan Brodsky, dalam Hesse, 2002). Beberapa peneliti yakin bahwa STS dihasilkan dari proses pemaparan dari pengalaman traumatik yang dialami oleh orang lain. Figley dan Stamm (Stamm, 1999) melihat bahwa pengalaman bekerja dengan klien yang mengalami trauma dapat mengubah diri 
seorang konselor atau terapis menjadi lebih baik atau buruk. Dengan demikian, peristiwa dan pengalaman traumatis klien juga mempengaruhi kehidupan pribadi konselor.

Anda mungkin pernah membaca kisah Sybil, kisah nyata seorang gadis dengan 16 kepribadian yang ditulis oleh Flora Rheta Schreiber (1973) yang diterjemahkan oleh Sarlito W.Sarwono (1984). Kisah tragis yang dialami seorang anak perempuan bernama Sybil dibesarkan dalam lingkungan keluarga yang picik, serba mengharamkan, kejam, dan tidak memberi peluang untuk jalan keluar. Split of personality merupakan gejala hysteria melawan pengalaman traumatis yang dialaminya. Menarik dalam buku ini diceritakan bahwa Sybil dirawat oleh seorang psikiater bernama Dr. Wilbur, yang lebih kurang selama 35 tahun merawat Sybil sehingga semua kepribadiannya kembali menyatu. Pada bagian cerita itu dihalaman 394 paragraf ke 3, penulis menemukan pernyataan sebagai berikut: " Dengan mempertimbangkan parahnya problem-problem yang sedang dihadapi oleh pasiennya maupun dirinya sendiri, Dr. Wilbur menyadari bahwa ia sdang menghadapi krisis professional."

Kalimat ini, penulis maknai bahwa terjadi STS dalam diri Dr. Wilbur. Dapat dibayang, menghadapi klien yang memiliki kepribadian sebanyak 16 dengan karakteristik tingkah laku berbeda-beda, dan itu dilayani lebih dari 35 tahun. Ada saatnya Dr. Wilbur, mengalami stress dari peristiwa traumatis yang dialami kliennya.

Terkait dengan itu menurut Beaton dan Murphy (dalam Cornille, 1999), individu yang mengalami STS umumnya menunjukkan simtom-simtom yang sama dengan PTSD, antara lain :Adanya gangguan tidur,Kemarahan, Ketakutan yang intense, Gangguan memory, Sensitif, Cemas, Menekan emosi tertentu, Mimpi buruk, Kehilangan control, Depresi, Tendensi untuk bunuh diri. Selanjutnya, efek dari STS itu sendiri akan mengganggu fungsi profesional individu.

\section{DISKUSI PROFESIONAL: STRATEGI MENGATASI STS PADA KONSELOR}

Konselor perlu mewaspadai STS. Terkait STS kepribadian dari seorang konselor sangat kurisal dalam menciptakan perubahan pada klien dibanding kemampuan mereka dalam menguasai pengetahuan, keahlian atau teknik (McAuliffe \& Lovell, Roger , 1961, dalam Samuel T. Gladding, 2012: 40). Konselor yang efektif bertumbuh sebagai seorang manusia dan menolong yang lain untuk melakukan hal yang sama, baik secara profesional maupun global. Dengan kata lain, konselor yang efektif bertumbuh sebagai seorang manusia dan menolong yang lain untuk melakukan hal yang sama, baik secara personal maupun global. Dengan kata lain, konselor yang efektif peka terhadap diri mereka dan orang lain. Mereka memonitor prasangka mereka, mendengarkan, mencari klarifikasi, mengeksplorasi perbedaan kultural dan rasial secara terbuka dan positif (Ford, Harris, \& Schuerger, 1993 dalam Samuel T. Gladding, 2012: 40).

Kemampuan konselor untuk bekerja dari perpekstif pengalaman emosional yang sudah teratasi yang membuat seseorang peka terhadap diri sendiri dan orang lain adalah karakter yang disebut Rollo May sebagai penyembuh luka (May, Remen, Young, \& Berland, 1985 Samuel T. Gladding, 2012: 41). Hal ini merupakan fenomena paradoks. Individu yang pernah tersakiti dan mampu mengatasi rasa sakit tersebut serta memperoleh wawasan untuk diri sendiri dan dunia akan mampu menolong orang lain yang berjuang untuk mengatasi masalah emosionalnya (Miller, Wagner, Britton, \& Gridley, 1998). Mereka telah merasakan apa yang klien rasakan. Jadi, konselor yang mempunyai pengalaman hidup menyakitkan dan mampu menanganinya, biasanya mampu berkomunikasi dan bersikap jujur (autentik) dengan klien yang mempunyai masalah (Foster, 1996 dalam Samuel T. Gladding, 2012: 41).

Samuel T. Gladding, (2012: 41) menegaskan seorang konselor yang efektif memilih dan mengatur waktu tindakan mereka secara intuitif dan didasarkan pada apa yang menurut hasil pengamatan adalah yang terbaik. Akan sangat membantu apabila selama hidupnya konselor tersebut sudah mengalami berbagai macam pengalaman hidup yang memungkinkan mereka menyadari apa yang akan atau tengah dialami klien mereka sehingga waspada dan bertindak tepat. 
Auvenshine dan Noffsinger (1984) dalam Samuel T. Gladding,( 2012:44) menyatakan konselor yang efektif adalah konselor yang secara emosi dewasa, stabil, dan objektif. Mereka memiliki kesadaran diri dan matap dalam kesadaran tersebut serta mampu mengelola kelebihan dan kekurangan mereka secara realistis.

Menghadapi pengalaman STS yang dirasakan konselor maka sebagai individu yang efektif seperti digambarkan di atas, konselor harus mampu mengatasi STSnya. Sebagai sebuah profesi dan disisi lain sebagai manusia yang merupakan makhluk sosial, maka diperlukan orang lain sesama profesional dalam

mengatasi persoalan STS yang dialami oleh konselor.

Diskusi profesional adalah : pembahasan masalah yang dialami oleh klien yang dihadiri oleh 2 orang atau lebih.Batasan yang tidak boleh dilampau dalam melakukan diskusi profesional adalah (1) diikuti oleh orang-orang yang memahami bimbingan konseling, (2)tidak menyebutkan nama klien (3) tujuannya posititf, objektif dan ilmiah yaitu untuk kepentingan dan kebahagiaan klien, (4) tidak membicarakan pribadi klien secara negatif (5) memelihara azas kerahasiaan.

Hal yang dibahas dalam diskusi profesional biasanya adalah masalah klien yang sudah, akan/belum dan sedang ditangani dalam konseling. Jelas dalam hal ini manfaat dari diskusi profesional yaitu : (1) menambah wawasan konselor dalam melayani klien, (2) membantu konselor memahami persoalan-persoalan yang rumit yang dialami oleh konselor dan (3) konselor dapat mengoreksi kesalahan-kesalahan yang dilakukannya. Dalam hal ini sekali lagi diskusi profesional menjadi wadah bagi konselor untuk mengatasi STS yang dirasakannya.

Secara formal sebenarnya bagi konselor sekolah di Indonesia, mereka memiliki forum MGP (musyawarah Guru Pembimbing) dan diskusi profesional yang diselenggarakan periodik seperti $1 \mathrm{x}$ dalam sebulan. Legal formal bagi forum ini adalah PP No.38 Th 1992 tentang Tenaga Kependidikan, bab XIII, pasal 61 aya (1) menyatakan bahwa tenaga kependidikan dapat membentuk ikatan profesi sebagai wadah untuk meningkatkan dan/atau mengembangkan karir, kemampuan, kewenangan professional, martabat dan kesejahteraan tenaga kependidikan demi tercapainya tujuan pendidikan secara optimal. Forum atau wadah ini menjadi tempat bagi Guru Pembimbing/guru BK atau konselor sekolah untuk melakukan diskusi profesional.

Dalam Petunjuk penyelenggaraan MGP (1996) dijelaskan MGP adalah forum/wadah kegiatan profesional Guru pembimbing dari sejumlah sekolah. Pengertian Musyawarah mencerminkan kegiatan dari, oleh dan untuk sesama peserta dalam hal ini Guru Pembimbing (SLTP/SMU Negeri maupun Swasta) yang mengasuh dan bertanggungjawab melaksanakan kegiatan bimbingan dan konseling di sekolah. Tujuan MGP adalah :

a. menumbuhkembangkan kegiatan Guru Pembimbing untuk meningkatkan kemampuan dan keterampilan dalam mempersiapkan, melaksanakan, mengevaluasi, menganalisis dan menindaklanjuti program kegiatan Bk dalam rangka meningkatkan keyakinan diri sebagai Guru pembimbing profesional.

b. Menyetarakan kemampuan dan kemahiran profesional Guru Pembimbing dalam melaksanakan kegiatan BK sehingga dapat menunjang usaha peningkatan dan pemerataan mutu serta keterkaitan dan kesepadanan pendidikan.

c. Mendiskusikan permasalahan yang dihdapi oleh Guru Pembimbing dalam melaskanakan tugas sehari-hari dan mencari cara penyelesaian yang sesuai dengan karakteristik pelayanan BK, pribadi Guru Pembimbing, Kondisi sekolah dan lingkungan.

d. Membantu Guru Pembimbing memperoleh informasi teknis edukatif yang berkaitan dengan kegiatan keilmuan, teknologi, kegiatan pelaksanan pelayanan BK dan berbagai kebijakan

e. Saling berbagi informasi dan pengalaman dalam rangka mengikuti perkembangan ilmu pengetahuan dan teknologi BK 
f. Membantu GP dalam melatih diri untuk berbagai keterampilan dalam melaksanakan layanan, kegiatan pendukung dan kegiatan penunjang BK dengan motto BK Peduli Siswa

g. Membantu GP dalam menegakkan kode egtik profesional BK

Berdasarkan penjelasan di atas, dapat dilihat bahwa Konselor sekolah, perlu melakukan diskusi profesional dengan memanfaatkan forum Musyawarah Guru Pembimbing (MGP) tersebut. Pelaksanaan diskusi profesional secara rutin akan meminimalisir kondisi STS yang dialami oleh konselor.

\section{PENUTUP}

Secara natural, empati yang dilakukan konselor pada klien yang mengalami peristiwa traumatis dan keinginan yang kuat untuk membantu memungkinkan terjadinya secondary traumatic stress. Konselor perlu mewaspadainya dan mengatasinya dengan melakukan diskusi professional. Pengalaman traumatis yang dirasakan konselor dan dapat diatasi, akan membantunya sehingga memiliki kemampuan berkomunikasi dan bersikap jujur (autentik) dengan klien yang mempunyai masalah yang sama di kemudian hari.

\section{DAFTAR PUSTAKA}

Baird,S., Jenkins, S.R. (2003). Vicarious Traumatization, Secondary Traumatic Stress, and Burnout in Sexual Assault and Domestic Violence Agency Staff. Journal Violence and Victims, vol. 18, 71-85.

Birck, A. (2001). Secondary Traumatization and Burnout in Professional Working with Torture Survivors. Traumatology, vol. 7, 1-4.

Cornille, T.A. \& Meyers, T.W. (1999). STS Among Child Protective Service Workers: Prevalence, Severity and Predictive Factors. Traumatology, vol. 2, 71-93.

Courtois,C.A. (1993). Vicarious Traumatization of The Therapist. NCP Clinical Newsletter 3, 2.

Depdikbud dan P3KG .(1996). Petunjuk Penyelenggaraan Musyawarah Guru Pembimbing. Jakarta: Depdikbud

Flora Rheta Schreiber. (1984). Sybil Kisah Nyata Seorang gadis dengan 16 Kepribadian (terjemahan oleh: Sarlito W. Sarwono). Jakarta: PT. Sinar Agape press.

Figley, C.R. (1995). Compassion Fatique : An Introduction. Advanced Intervention Methods. Florida State University Traumatology Institute.

Figley, C.R. \& Stamm, B.H. (1996). Psychometric Review of Compassion Fatique Self Test. Available at http://www.sidran.org/digicart/products/stms.html.

Hesse, A.R. (2002). Secondary Trauma : How Working with Trauma Survivors Affects Therapists. Clinical Social Work Journal, vol 30, 293 - 310.

Jenkins, S.R., Baird, S. (2002). Secondary Traumatic Stress and Vicarious Trauma : A Validational Study. Journal of Traumatic Stress, vol. 5, 423 - 432.

Lonergan, B.A. (1999). The Development of Trauma Therapist : A Qualitative Studi of the Therapist's Perspectives and Experiences. Colorado : Counselling Psychology.

Mc.Cann, I.L \& Saakvitne, K.W. (1995). Treating Therapists with Vicarious Traumatization and Secondary Traumatic Stress Disorder. Dalam C.R. Fifley (Ed), Compassion Fatique : Secondary Traumatic Stress Disorder from Treating the Traumatized. New York : Brunner/ Mazel, Publishers. 
Pickett,G.Y. (1998). Therapist in Distress : An Integrative Look at Burnout, Secondary Traumatic Stress and Vicarious Traumatization. Dissertation. University of Missouri-St. Louis.

Richardson, J.I. (2001). Guidebook on Vicarious trauma : Recommended Solutions for Anti-Violence Worker. Canada : Family Violence Prevention Unit.

Rudolph, J.M., Stamm, B.H., Stamm, H.E. (1997). Compassion Fatique : A Concern for Mental Health Policy, Providers, \& Administration. Poster at the 13th Annual Meeting of the International Society for Traumatic Stress Studies, Montreal, PQ,CA.

Samuel T. Gladding. (2012). Konseling : Profesi yang menyeluruh. Jakarta: PT. Indeks.

Schauben, L., \& Frazier, P. (1995). Vicarious trauma the effects on female counselors of working with sexual violence survivors. Psychology of Women Quarterly, 19, 49-64.

Sexton, L. (1999). Vicarious Traumatisation of Counsellors and Effects on Their Workpaces. British Journal of Guidance \& Counselling, 27, 3, $393-403$.

Sidabutar. S.I.E., Dharmawan. L.I., Poerwandari, K., Nurhaya,N. (2003). Pemulihan Psikososial Berbasis Komunitas. Refleksi Untuk Konteks Indonesia. Jakarta : Kontras.

Stamm, B.H. (1999). Secondary Traumatic Stress. Self Care Issues for Clinicians, Researchers \& Educators. MD : Sidran Press.

Steed, L.G. \& Bicknell (2001). Trauma and Therapist : The Experience of Therapist Working with the Perpetrator of Sexual Abuse. The Australian Journal of Disaster \& Trauma Studies, 1.

Steed, L.G. \& Downing, R. (1998). A Phenomenological Studi of VT Amongst Psychologist and Professional Counsellor Working in The Field of Sexual Abuse/ Assault. The Australian Journal of Disaster \& Trauma Studies.

Wibe, R.L. (2001). The Influence of Personal Meaning on Vicarious Traumatization in Therapist. Thesis : Trinity Western University. 